\title{
PERLINDUNGAN HUKUM TERHADAP ANAK AKIBAT DARI PERKAWINAN SIRI
}

\author{
Irwan Safaruddin $\mathrm{Hrp}^{1)}$, Ridwan Rangkuti ${ }^{2}$, Abdul Aziz Abidan ${ }^{3)}$ \\ Universitas Muhammadiyah Tapanuli Selatan \\ Irwan.safaruddin@um-tapsel.ac.id ${ }^{1)}$ \\ ridwan.rangkuti@um-tapsel.ac.id ${ }^{2)}$ \\ abdul.aziz@um-tapsel.ac.id ${ }^{3)}$
}

\begin{abstract}
Abstrak
Anak dari pernikahan siri kini dapat menuntut hak perdata dari ayahnya.Sekarang pemerintah akan menerbitkan akta kelahiran yang mencatat nama ayah dari anak hasil pernikahan siri. Seperti yang sudah tertulis pada Undang-Undang tentang Perubahan Undang-undang Nomor 23 Tahun 2006 tentang Administrasi Kependudukan di mana Undang-undang memerintahkan pengakuan anak untuk anak yang dilahirkan dari perkawinan yang telah sah menurut hukum agama, tetapi belum sah menurut hukum negara. Metode pendekatan Normatif, sifat penelitiannya deskriptif untuk melihat hokum dalam artinyata, dan meneliti bagaimana bekerjanya hukum di lingkungan masyarakat. Penelitian ini menggunakan jenis penelitian kepustakaan, dengan sumber data dalam penelitian memakai bahan hukum Primer dan sekunder. Pengelolahan dan analisis data yang digunakan dalam penelitian ini menggunakan metode kualitatif, dengan cara memadukan antara penelitian kepustakaan dan penelitian lapangan untuk meneliti efektivitas suatu undang-undang.
\end{abstract}

Kata kunci: Perlindungan Hukum, Anak, Perkawinan Siri

\begin{abstract}
Children from siri marriages can now sue for civil rights from their father. Now the government will issue a birth certificate that records the father's name of the child from the siri marriage. As already written in the Law concerning Amendments to Law Number 23 of 2006 concerning Population Administration where the Law instructs the recognition of children for children born from marriages that have been valid according to religious law, but are not yet legal according to state law. Normative approach method, the nature of the research is descriptive to see the law in artinyata, and examine how the law works in the community. This study uses a type of library research, with data sources in the study using primary and secondary legal materials. Management and analysis of the data used in this study using qualitative methods, by combining library research and field research to examine the effectiveness of a law.
\end{abstract}

Keywords: Legal Protection, Children, Siri Marriage

\section{PENDAHULUAN}

Anak merupakan generasi yang perlu dilindungi oleh berbagai unsur, Setiap anak mempunyai hak asasi, sebagaimana hak yang dimiliki oleh orang dewasa. Tidak banyak pihak yang turut memikirkan dan mau melakukan langkah-langkah kongkret untuk melindungi hak anak. Upaya untuk melindungi hak-hak dan masa depan anak, orang dewasa, lingkungan sendiri, atau orangtuanyapun masih belum begitu di perhatikan. Padahal anak merupakan belahan jiwa, gambaran dan cermin masa depan, aset keluarga, agama serta bangsa dan negara.

Anak sebagai hasil dari suatu perkawinan merupakan bagian yang sangat penting kedudukannya dalam suatu keluarga menurut Hukum Perkawinan Islam. Dalam Islam anak adalah anak yang 
dilahirkan yang tercipta melalui ciptaan Allah dengan perkawinan seorang laki-laki dan seorang perempuan. Di dalam Al-Qur'an, anak sering disebutkan dengan kata waladawlâd yang berarti anak yang dilahirkan orang tuanya, laki-laki maupun perempuan, besar atau kecil, tunggal maupun banyak. Karenanya jika anak belum lahir belum dapat disebut al-walad atau al-mawlûd, tetapi disebut al-janin yang berarti al-mastûr (tertutup) dan al-khafy (tersembunyi) di dalam rahim ibu. (Lois Ma'luf, al-Munjid, t.th: 1019 dan 99.)

Dalam Hukum Islam anak yang sah dilahirkan sekurang-kurangnyaenam bulan (177 hari) semenjak pernikahan orang tuanya, tidak perduli apakah orang itu lahir sewaktu orang tuanya masih terikat dalam perkawinan ataukah sudah berpisah karena wafatnya si suami, atau karena perceraian di masa hidupnya. Dan jika anak itu lahir sebelum genap jangka waktu 177 hari itu maka anak itu hanya sah bagi ibunya dari perkawinan resminya. Di luar ketentuan itu adalah anak dianggap sebagai anak tidak sah atau anak zina.

Untuk memastikan bahwa anak apakah sungguh-sungguh anak ayahnya (dapat dinisbahkan kepada suami ibunya) yang sah, para fukaha menetapkan ada tiga dasar yang dapat dipergunakan untuk menentukan apakah anak yang sah atau tidak:

\section{a) Tempat Tidur Yang Sah (Al-Firasyus Shahih)}

Yang dimaksud dengan tempat tidur yang sah adalah adanya tali perkawinan yang sah antara ayah dan ibu si anak semenjak mulai mengandung. Maka apabila bayi yang dalam kandungan itu lahir, keturunannya dihubungkan kepada keduaorang tuanya, tidak diperlukan lagi adanya pengakuan dari pihak si ayah dan bukti-bukti lain untuk menetapkan keturunannya. Dengan adanya tempat tidur yang sah ini sudahcukup sebagai alasan untuk menetapkan bahwa anak yang adaadalah anak yang sah. Tempat tidur yang sah baru dapat dijadikan dasar untuk menetapkan keturunan anak yang sah apabila telah memenuhi tiga syarat berikut ini, yaitu : 1) Suami telah mencapai usia baligh atau sekurang-kurangnya mendekati usia baligh. 2) Tenggang kandungan terpendek adalah 6 bulan, sejak akad nikah dilangsungkan. 3) Suami tidak menyangkal sahnya anak yang dilahirkan oleh isterinya tersebut. (Yusuf al-Qardhawi, 1976; 256).

\section{b) Pengakuan}

Seorang anak yang sah dapat ditetapkan dengan melalui pengakuan dengan syarat : 1) Orang yang diakui itutidak dikenal keturunannya. 2) Adanya kemungkinan orang yangdiakui itu sebagai anak bagi orang yang mengakuinya. 3) Pengakuan itu dibenarkan oleh anak yang diakuinya. Apabila syarat-syarat itu telah dipenuhi maka anak yang diakui itu sebagai anak sah dari yang mengakuinya.

\section{c) Saksi}

Keturunan anak yang sah dapat juga ditentukan denganadanya bukti yang konkret seperti adanya dua orang saksi laki-laki atau seorang laki-laki dan dua orang wanita. Apabilaseseorang mengakui bahwa seseorang yang lain adalahanaknya yang sah sedang orang yang diakui itu menolak, makayang mengakui dapat mengemukakan dua orang saksi sebagaibukti dan hakim memutuskan bahwa orang yang diakui ituadalah anak yang sah. Dari uraian tersebut dapatdikuatkan pendapat bahwa status hukum anak hasil dariperkawinan wanita hamil menurut hukum Islam adalah apabilaanak tersebut lahir sekurangkurangnya enam bulan daripernikahan yang sah kedua orang tuanya, maka anak tersebutadalah anak sah dan dapat dinasabkan kepada kedua orangtuanya.

Apabila anak itu lahir kurang dari enambulan semenjak pernikahan yang sah kedua orang tuanya,maka anak tersebut adalah anak yang tidak sah dan tidak dapatdinasabkan kepada kedua orang tuanya.Anak ini hanyamempunyai hubungan nasab kepada ibunya saja.

Dalam hukum Islam seseorang suami dapat menolak untuk mengakui bahwa anak yang dilahirkan istrinya bukanlah anaknya, selama suami dapat membuktikanya, untuk menguatkan penolakannya suami harus dapat membuktikan bahwa Suami belum pernah menjima' istrinya, akan tetapi istri tiba-tiba melahirkan, Lahirnya anak itu kurang dari enam bulan sejak menjima' istrinya, 
sedangkan bayinya lahir seperti bayi yang cukup umur, Bayi lahir sesudah lebih dari empat tahun dan si istri tidak dijima' suaminya.

\section{Rumusan Masalah}

Berdasarkan latar belakang masalah diatas maka peneliti merumuskan masalah dari penelitian ini adalah :

1. Bagaimana Perlindungan Hukum terhadap anak dari hasil perkawinan sirih ?

2. Bagaimanakah kedudukan anak yang lahir dari perkawinan sirih terhadap warisan?

\section{METODE \\ Tujuan Penelitian}

Tujuan penelitian ini adalah untuk memahami perlindungan hukum terhadap anak dari hasil perkawinan sirih serta memahami kedudukan anak yang lahir dari perkawinan sirih terhadap warisan akibat dari perkawinan siri.

\section{Kajian Perlindungan Hukum terhadap Anak}

Anak seyogyanya di pandang sebagai aset berharga dari suatu bangsa dan negara di masa mendatang yang harus dijaga dan dilindungi hak-haknya. Bagaimanapun juga, di tangan anakanaklah kemajuan suatu bangsa akan ditentukan. Semakin modern suatu negara, maka semakin besar perhatiannya dalam menciptakan kondisi yang kondusif bagi tumbuh kembang anak-anak dalam rangka memberi perlindungan hukum. Perlindungan yang diberikan negara terhadap anak meliputi berbagai aspek kehidupan yaitu: aspek ekonomi, sosial, budaya, politik, hankam maupun aspek hukum.

Mendapatkan

perlindungan

merupakan hak dari setiap anak dan diwujudkannya perlindungan bagi anak berarti terwujudnya keadilan, kepastian hukum, dan kesejahteran dalam suatu masyarakat. Asumsi ini diperkuat dengan pendapat Age yang ditegaskan oleh Arif Gosita yang mengemukakan bahwa melindungi anak pada hakekatnya melindungi keluarga, masyarakat, bangsa dan negara di masa depan(Arif
Gosita,1996:1). Dari ungkapan tersebut, maka dapat dinyatakan upaya perlindungan anak sangat penting demi kelangsungan masa depan sebuah komunitas, baik komunitas yang terkecil yaitu keluarga, maupun komunitas yang terbesar yaitu negara.

Perlindungan anak merupakan suatu usaha yang mengadakan situasi dan kondisi yang memungkinkan pelaksanaan hak dan kewajiban anak secara manusiawi. Hal ini berarti bahwa dilindunginya hak anak dalam memperoleh dan mempertahankan haknya untuk hidup, mempunyai kelangsungan hidup, bertumbuh kembang, dan perlindungan dalam pelaksanaan hak dan kewajibannya sendiri atau bersama para pelindungnya .

Menurut Pasal 1 Nomor (a), Undangundang Nomor 35 Tahun 2014 tentang Perlindungan Anak disebutkan : "Perlindungan anak adalah segala kegiatan untuk menjamin dan melindungi anak dan hak-haknya agar dapat hidup, tumbuh, berkembang, dan berpartisipasi secara optimal sesuai dengan harkat dan martabat kemanusiaan, serta mendapat perlindungan dari kekerasan dan diskriminasi.

Selanjutnya menurut Peraturan Menteri Koordinator Bidang Kesra Republik Indonesia No 07 Tahun 2014 Tentang rencana aksi nasional perlindungan dan pemberdayaan perempuan dan anak dalam komplik sosial Tahun 2014-2019, pada Pasal 1 ayat(3), bahwa Perlindungan perempuan dan anak adalah upaya pencegahan dan penanganan dari segala bentuk tindak kekerasan dan pelanggaran hak asasi perempuan dan anak, serta memberikan layanan kebutuhan dasar dan spesifik perempuan dan anak dalam penanganan konflik sebagai bagian yang tidak terpisahkan dari kegiatan penanganan konflik.

Selanjutnya upaya ini lebih menitikberatkan pada hal yang integral, karena pelaksanaan perlindungan terhadap anak dapat berhasil, bila para pihak yang terkait seperti: orang tua, para petugas, dan pembina, tidak terlebih dahulu dibina, dibimbing, serta diberikan pemahaman mengenai cara melindungi anak dengan baik. Di tinjau dari sifat perlindungannya, perlindungan anak juga dapat dibedakan 
dari perlindungan bersifat yuridis, yang meliputi: perlindungan dalam bidang hukum perdata dan dalam hukum pidana, perlindungan yang bersifat non-yuridis, meliputi: perlindungan dibidang sosial, bidang kesehatan, dan bidang pendidikan .

Perlindungan yang bersifat yuridis lebih dikenal dengan perlindungan hukum.Hal ini dipertegas lagi oleh Arief Gosita, yang berkaitan dengan upaya perlindungan hukum terhadap berbagai kebebasan dan hak asasi anak (fundamental rights and freedoms of children) serta berbagai kepentingan yang berhubungan dengan kesejahteraan anak. Perlindungan hukum dalam bidang keperdataan, terakomodir dalam ketentuan di bidang hukum perdata yang mengatur mengenai anak seperti: (1) kedudukan anak sah dan hukum waris, (2) pengakuan dan pengesahan anak di luar kawin, (3) kewajiban orang tua terhadap anak, serta (4) kebelum dewasaan anak dan perwalian.

\section{Kajian Kedudukan Anak dari Aspek Hukum Perdata akibat Perkawinan Sirih Terhadap hak waris}

Jika berdasarkan Pasal 863 - Pasal

873 KUHPerdata, maka anak luar kawin yang berhak mendapatkan warisan dari ayahnya adalah anak luar kawin yang diakui oleh ayahnya (Pewaris) atau anak luar kawin yang disahkan pada waktu dilangsungkannya perkawinan antara kedua orang tuanya. Untuk anak luar kawin yang tidak sempat diakui atau tidak pernah diakui oleh Pewaris (dalam hal ini ayahnya), berdasarkan Putusan Mahkamah Konstitusi No. 46/PUU-VIII/2010 yang menguji Pasal 43 ayat (1) UUP, bunyi pasal tersebut adalah :

"Anak yang dilahirkan di luar perkawinan mempunyai hubungan perdata dengan ibunya dan keluarga ibunya serta dengan laki-laki sebagai ayahnya yang dapat dibuktikan berdasarkan ilmu pengetahuan dan teknologi atau alat bukti lain menurut hukum mempunyai hubungan darah, termasuk hubungan perdata dengan keluarga ayahnya".

Jadi anak luar kawin tersebut dapat membuktikan dirinya sebagai anak kandung dari pewaris. Namun demikian, jika mengacu pada Pasal 285 KUHPerdata yang menyatakan bahwa apabila terjadi pengakuan dari ayahnya, sehingga menimbulkan hubungan hukum antara pewaris dengan anak luar kawinnya tersebut, maka pengakuan anak luar kawin tersebut tidak boleh merugikan pihak istri dan anak-anak kandung pewaris. Artinya, anak luar kawin tersebut dianggap tidak ada.Oleh karena itu, pembuktian adanya hubungan hukum dari anak hasil perkawinan siri tersebut tidak menyebabkan dia dapat mewaris dari ayah kandungnya (walaupun secara tekhnologi dapat dibuktikan). Pendapat ini juga dikuatkan oleh Fatwa dari Majelis Ulama Indonesia tanggal 10 Maret 2012 yang menyatakan bahwa anak siri tersebut hanya berhak atas wasiat wajibah . Anak dari pernikahan siri kini dapat menuntut hak perdata dari ayahnya. Sekarang pemerintah akan menerbitkan akta kelahiran yang mencatat nama ayah dari anak hasil pernikahan siri. Seperti yang sudah tertulis pada UndangUndang tentang Perubahan UU Nomor 23 Tahun 2006 tentang Administrasi Kependudukan yang mana Undang-undang memerintahkan pengakuan anak untuk anak yang dilahirkan dari perkawinan yang telah sah menurut hukum agama, tetapi belum sah menurut hukum negara.

Hal ini untuk melindungi hak perdata anak. Dengan pengakuan anak dimaksud, anak yang bersangkutan mempunyai hubungan perdata dengan ayahnya, dalam konteks diatas maka akta tersebut akan mencatat nama ayah anak hasil nikah siri. klausal tersebut merupakan pelaksanaan putusan Mahkamah Konstitusi (MK) atas uji UU Nomor 1 Tahun1974 tentang Perkawinan. Ini impliakasi atas putusan MK yang menyatakan ayah mempunyai tanggung jawab perdata terhadap anaknya meski anak di luar nikah.

Undang-undang ini telah dirancang dalam peraturan pemerintah (PP) atau peraturan presiden (perpres) sebagai dasar hukum pelaksana aturan itu.Dan sekarang MK memutuskan anak yang lahir di luar pernikahan tetap memiliki hubungan perdata dengan ayah kandung sepanjang dapat dibuktikan.Putusan itu dibacakan Februari 2013 lalu. Anak Luar Kawin Menurut Kitab Undang-Undang Hukum 
Perdata (Kuhperdata) Dan Undang-Undang Nomor 1 Tahun 1974 Tentang Perkawinan

Anak luar kawin yang diakui secara sah adalah salah satu ahli waris menurut undang-undang yang diatur dalam KUHPerdata berdasarkan Pasal 280 jo Pasal 863 KUHPerdata. Anak luar kawin yang berhak mewaris tersebut merupakan anak luar kawin dalam arti Sempit, mengingat doktrin mengelompokkan anak tidak sah dalam 3 (tiga) kelompok, yaitu anak luar kawin, anak zina, dan anak sumbang, sesuai dengan penyebutan yang diberikan oleh pembuat undang-undang dalam Pasal 272 jo 283 KUHPerdata (tentang anak zina dan sumbang). Anak luar kawin yang berhak mewaris adalah sesuai dengan pengaturannya dalam Pasal 280 KUHPerdata.

Pembagian seperti tersebut dilakukan, karena undang-undang sendiri, berdasarkan ketentuan-ketentuan yang ada, memang memberikan akibat hukum lain-lain (sendiri-sendiri) atas status anakanak seperti tersebut di atas. Sekalipun anak zina dan anak sumbang, sebenarnya juga merupakan anak luar kawin dalam arti bukan anak sah, tetapi kalau dibandingkan dengan Pasal 280 dengan Pasal 283 KUH Perdata, dapat diketahui anak luar kawin menurut Pasal 280 dengan anak zina dan anak sumbang yang dimaksud dalam Pasal 283 adalah berbeda.

Demikian pula berdasarkan ketentuan Pasal 283, dihubungkan dengan Pasal 273 KUHPerdata, bahwa anak zina berbeda dengan anak sumbang dalam akibat hukumnya. Terhadap anak sumbang, undang-undang dalarn keadaan tertentu memberikan perkecualian, dalam arti, kepada mereka yang dengan dispensasi diberikan kesempatan untuk saling menikahi (Pasal 30 ayat (2) KUHPerdata) dapat mengakui dan mengesahkan anak sumbang mereka menjadi anak sah (Pasal 273 KUHPerdata). Perkecualian seperti ini tidak diberikan untuk anak zina.

Perbedaan antara anak luar kawin dan anak zina terletak pada saat pembuahan atau hubungan badan yang menimbulkan kehamilan, yaitu apakah pada saat itu salah satu atau kedua-duanya (maksudnya laki-laki dan perempuan yang mengadakan hubungan badan di luar nikah) ada dalam ikatan perkawinan dengan orang lain atau tidak, sedangkan mengenai kapan anak itu lahir tidak relevan. Anak zina adalah anak-anak yang dilahirkan dari hubungan luar nikah antara seorang laki-laki dan seorang perempuan di mana salah satu atau kedua-duanya, terikat perkawinan dengan orang lain.

Adapun anak sumbang adalah anakanak yang dilahirkan dari hubungan antara seorang laki-laki dan seorang perempuan, yang antara keduanya berdasarkan ketentuan undang-undang ada larangan untuk saling menikahi (Pasal 31 KUHPerdata).

Dengan demikian anak luar kawin dalam arti sempit adalah anak yang dilahirkan dari hasil hubungan antara seorang laki-laki dan seorang perempuan, yang kedua-duanya tidak terikat perkawinan dengan orang lain dan tidak ada larangan untuk saling menikahi, anakanak yang demikianlah yang bisa diakui secara sah oleh ayahnya (Pasal 280 KUHPerdata).Hubungan antara ibu dan anak terjadi dengan sendirinya karena kelahiran, kecuali apabila anak itu "overspelig atau bloedsrhenning (anak zinah).Antara ayah dan anak hanya terjadi hubungan perdata karena pengakuan (Pasal 280 KUHPerdata).

Selanjutnya diperjelas lagi oleh Pasal 280 KUHPerdata, yang mengatakan; bahwa dengan pengakuan yang dilakukan terhadap seorang anak luar kawin, timbullah hubungan perdata antara anak dan bapak atau ibunya. Hal ini berarti, bahwa antara anak luar kawin dan "ayah" (biologisnya) maupun "ibunya" pada asasnya tidak ada hubungan hukum. hubungan hukum itu baru ada kalau "ayah" dan atau "ibunya"memberikan pengakuan, bahwa anak itu adalah anaknya. Dengan demikian, tanpa pengakuan dari ayah dan atau ibunya, pada asasnya anak itu bukan anak siapa-siapa.la tidak mempunyai hubungan hukum dengan siapa pun.

Hubungan yang kokoh dari hubungan pertalian darah oleh hukum syara' diberikan hak dan kewajiban antara orang tua dan anak. Adanya hubungan nasab antara orang tua dengan anak, menimbulkan hak-hak anak atas orang tuanya. Menurut Wahbah al-Zuhaili, ada 
lima macam hak anak terhadap orang tuanya, yaitu hak nasab (keturunan), hak radla' (menyusui), hak hadlanah (pemeliharaan), hak walâyah (wali), dan hak nafkah (alimentasi).

Dengan terpenuhinya lima kebutuhan ini, orang tua akan mampumengantarkan anaknya dalam kondisi yang siap untuk mandiri. yaitu :

a) Hak Radla'

Hak Radla' artinya hak anak untuk mendapatkan pelayanan makanan pokoknya dengan jalan menyusu pada ibunya.Dan dalam masa penyusuan ini yang bertanggungjawab dalam hal pembiayaannya adalah kerabat terdekatmenurut garis nasab dan dalam hal ini ayahlah yang memiliki kedudukan tersebut.

b) Hak Hadlanah

Menurut Bahasa, kata meletakkansesuatu dekat tulang rusuk seperti menggendong, atau meletakkan sesuatu dalam pangakuan. Menurut istilah fikih, hadlanah ialah tugas menjaga dan mengasuh atau mendidik bayi atau anak kecil sejak ia lahir sampai mampu menjaga danmengatur dirinya sendiri.

Hukum positif di Indonesia membedakan antara keturunanyang sah dan keturunan yang tidak sah. Keturunan yang sah didasarkan atas adanya perkawinan yang sah, dalam arti, bahwa yang satu adalah keturunan yang lain berdasarkan kelahiran dalam atau sebagai akibat perkawinan yang sah, anak-anak yang demikian disebut anak sah. Sedangkan keturunan yang tidak sah adalah keturunan yang tidak didasarkan atas suatu perkawinan yang sah,orang menyebut anak yang demikian ini adalah anak luar kawin.

Menurut Riduan Syahrani dalam bukunya "Seluk Beluk dan Asas-asas Hukum Perdata", bahwa anak yang dilahirkan diluar perkawinan yang sah adalah bukan anak yang sah, sehingga membawa konsekuensi dalam bidang perwarisan. Sebab anak yang dilahirkan di luar perkawinan hanya mempunyai hubungan perdata dengan ibunya dan keluarga ibunya. (Riduan Syahrani,1989:100-101)

Menurut Undang-undang Perkawinan dan Kompilasi Hukum Islam, anak yang sah adalah anak yang dilahirkan dalam atau akibatperkawinan yang sah, meskipun anak tersebut lahir dari perkawinan wanita hamil yang usia kandungannya kurang dari enam bulan lamanya sejak ia menikah resmi. Hal ini diatur dalam Undang-undang No. 1 Tahun 1974 Pasal 42 :"Anak yang sah adalah anak yang dilahirkan dalam atau akibat perkawinan yang sah".

Pasa1 43 (UUP) :

(1) Anak yang dilahirkan di luar perkawinan hanya mempunyai hubungan perdata dengan ibunya dan keluarga ibunya.

(2) Kedudukan anak tersebut ayat (1) di atas selanjutnya akan diatur dalam Peraturan Pemerintah".

Pasa1 44

(1) Seorang suami dapat menyangkal sahnya anak yang dilahirkan oleh istrinya bilamana ia dapat membuktikan bahwa istrinya telah berzina dan anak itu akibat daripada perzinaan tersebut.

(2) Pengadilan memberikan keputusan tentang sah/tidaknya anak atas permintaan pihak yang berkepentingan".Berkenaan dengan pembuktian asal-usul anak,

Undang-undang Perkawinan di dalam Pasal 55 menegaskan:

1. Asal-usul seorang anak hanya dapat dibuktikan dengan akta kelahiran yang otentik, yang dikeluarkan oleh Pejabat yang berwenang.

2. Bila akta kelahiran tersebut dalam ayat (1) pasal ini tidak ada, maka Pengadilan dapat mengeluarkan penetapan tentang asal-usul seorang anak setelah diadakan pemeriksaan yang teliti berdasarkan bukti-bukti yang memenuhi syarat.

3. Atas dasar ketentuan Pengadilan tersebut ayat (2) pasal ini, makainstansi Pencatat Kelahiran yang ada dalam daerah hukum Pengadilan yang bersangkutan mengeluarkan akta kelahiran bagi anak yang bersangkutan. 
Di dalam pasal-pasal di atas ada beberapa hal yang diatur. Pertama, anak sah adalah yang lahir dalam dan akibat perkawinan yang sah. Paling tidak ada dua bentuk kemungkinan:

a. Anak sah lahir akibat perkawinan yang sah

b. Anak yang lahir dalam perkawinan yang sah.

Dalam Kompilasi Hukum Islam asalusul anak diatur dalam Pasa1 99, Pasal 100, Pasal 101 Pasal 102 dan Pasal 103.

Pasal 99 :

Anak sah adalah:

a. Anak yang dilahirkan dalam atau akibat perkawinan yang sah.

b. Hasil pembuahan suami isteri yang sah di luar rahim dan dilahirkan oleh isteri tersebut.

Pasa100:

"Anak yang lahir di luar perkawinan hanya mempunyai hubungan nasab dengan ibunya dan keluarga ibunya".

Pasal 101 dan Pasal 102 menyangkut keadaan suami yang mengingkari sahnya anak dan proses yang harus ditempuhnya jika ia menyangkal anak yang dikandung atau dilahirkan oleh isterinya.

Pasal 101:

"Seorang suami yang mengingkari sahnya anak, sedang isteri tidak menyangkalnya, dapat meneguhkan pengingkarannya dengan li'an."

Pasal 102 :

(1) Suami yang akan mengingkari Pengadilan Agama dalam jangka waktu 180 hari sesudah hari lahirnya atau 360 hari sesudah putusnya perkawinan atau setelah suami itu mengetahui bahwa isterinya melahirkan anak dan berada di tempat yang memungkinkan dia mengajukan perkaranya kepada Pengadilan Agama.

(2) Pengingkaran yang diajukan sesudah lampau waktu tersebut tidak dapat diterima.

Pasa 1103 :

1. Asal-usul seorang anak hanya dapat dibuktikan dengan akta kelahiran atau alat bukti lainnya.

2. Bila akta kelahiran atau alat bukti lainnya tersebut dalam ayat (1) tidak ada, maka Pengadilan Agama dapat mengeluarkan penetapan tentang asal-usul seorang anak setelah mengadakan pemeriksaan yang teliti berdasarkan bukti-bukti yang sah.
3. Atas dasar ketetapan Pengadilan Agama tersebut ayat (2) maka instansi Pencatat Kelahiran yang ada dalam daerah hukum Pengadilan Agama tersebut yang mengeluarkan akta kelahiran bagi anak yang bersangkutan.

Kemudian dalam Pasal 250 Kitab Undang-undang Hukum Perdatamengatakan bahwa: "Tiap anak yang dilahirkan atau ditumbuhkan sepanjang perkawinan, memperoleh si suami sebagai bapaknya".

\section{Lokasi Penelitian}

Penelitian akan dilakukan di Kantor Pengadilan Agama Padangsidimpuan, Pengadilan Agama Mandailing natal dan Pengadilan Agama Tapanuli Selatan

\section{Pendekatan penelitian}

Setiap peristiwa hukum tertentu yang terjadi dalam masyarakat akan diteliti melalui pendekatan. Penelitian ini melakukan pendekatan kepustakaan dan wawancara dalam tujuan untuk pengumpulan data, baik data primer, skuner maupun tersiar. Pendekatan secara empiris atau wawancara diselenggarakan guna memperoleh keterangan dalam pelaksanaan suatu peraturan yang berkaitan dengan permasalahan.

\section{Jenis Penelitian}

Berdasarkan tujuan yang hendak dicapai pada penelitian ini, maka jenis hasil penelitian ini nantinya adalah yuridis normatif yaitu mengambarkan peraturan hukum yang berlaku dikaitkan dengan teoriteori hukum dan praktek pelaksanan hukum positif yang menyangkut permasalahan .

\section{Teknik Pengumpulan Data}

Metode pengumpulan data yang dilakukan adalah studi kepustakan sebagai bahan referensi untuk menunjang keberhasilan penelitian ini meliputi:

1. Bahan hukum primer adalah ketentuan hukum positif yang mengikat dan merupakan hukum positif yang berlaku yakni Undang-undang Nomor 1 Tahun 1974 tentang Perkawinan dan Kompilasi Hukum Islam.

2. Bahan Hukum Sekunder yaitu bahan yang memberikan penjelasan tentang 
bahan hukum primer, meliputi literatur bukubuku, pendapat para ahli yang ada hubungannya dengan penelitian ini dan peraturan perundang-undangan.

Studi lapangan dilakukan dengan wawancara, metode wawancara terarah yaitu melakukan tanya jawab secara langsung dengan responden untuk mendapatkan data primer mempersiapkan terlebih dahulu daftar pertanyaan sebagai pedoman dan masih dimungkinkan adanya variasi pertanyaan yang disesuaikan dengan situasi ketika wawancara dilakukan.

\section{Teknik Analisis Data}

Sebagai cara untuk menarik kesimpulan dari hasil penelitian yang sudah terkumpul, akan digunakan analisis kualitatif. peneliti bertitik tolak dari peraturan yang ada sebagai norma hukum positif, sedangkan kualitatif dimaksudkan yaitu analisis yang bertitik tolak pada usaha penemuan informasi dari responden, memahami kebenaran yang diperoleh dari hasil pengamatan dan pertanyaan kepada sejumlah responden baik secara lisan maupun tertulis selama dalam melakukan penelitian.

\section{SIMPULAN DAN SARAN Kesimpulan}

A. Perlindungan Hukum terhadap anak dari hasil perkawinan siri

Perkawinan siri hanya diakui secara agama. Sedangan menurut hukum Indonesia, perkawinan tersebut tidak sah karena tidak dicatatkan. Akibatnya, anakanak yang dilahirkan dari hasil nikah siri itu status hukumnya sama dengan anak luar kawin, yakni hanya punya hubungan hukum dengan ibunya

\section{B. Kedudukan anak yang lahir dari perkawinan siri terhadap warisan}

Bahwa anak tersebut adalah anak sah, tetapi tidak mempunyai bukti otentik yang dapat menguatkan bahwa anak tersebut adalah sah dari kedua orang tuanya. Hal ini menimbulkan dampak yang tidak baik pada kehidupan anak tersebut dikemudian hari, hak-hak anak tersebut dapat terlanggar seperti anak tersebut tidak mempunyai hak untuk mewaris dari ayahnya secara hukum negara, meski secara agama anak tersebut mempunyai hak atas hal tersebut. Sehingga perlu upaya hukum agar anak tersebut memperoleh status sebagai anak sah dari kedua orang tuanya.

\section{Saran}

Untuk kepentingan administrasi, Undang-Undang Perkawinan membagi penduduk Indonesia menjadi penduduk yang beragama Islamdan penduduk beragama selain Islam. Semua warga negara yang beragama Islam baik dari suku mana saja yang melakukan perkawinan secara Islam maka perkawinannya dicatat di Kantor Urusan Agama, sedangkan penduduk yang beragama selain Islam, melakukan perkawinan menurut agamanya, maka perkawinannya dicatat di Kantor Catatan Sipil. Lembaga Catatan Sipil adalah suatu lembaga yang diadakan oleh Pemerintah yang bertugas untuk mencatat atau mendaftarkan setiap peristiwa penting yang dialami warga masyarakat seperti perkawinan, perceraian, kelahiran, kematian dan pengakuan, yang dipergunakan sebagai pembuktian tentang adanya atau telah terjadinya peristiwaperistiwa tersebut. Begitu pula dengan adanya kehadiran seorang anak yang lahir dari perkawinan sah ('perkawinan yang dicatatkan') kedua orang tuanya telah membuktikan anak tersebut adalah anak kandung yang sah dari ayah dan ibunya. Akibat hukumnya apabila .perkawinan tidak dicatatkan (secara umum sering dikenal sebagai "perkawinan siri"), status anak yang dilahirkan dari perkawinan tersebut akan menjadi tidak pasti, karena perkawinan kedua orang tuanya hanya sah secara agama.

\section{DAFTAR PUSTAKA}

Buku:

Arif Gosita, 1996, Masalah Perlindungan Anak. Jakarta: Akademika Pressindo.

Ma'luf, Lois,al-Munjid,tth., al Mathba'ah alKatsolikiyyah, Beirut.

Syahrani, Riduan, 1989, Seluk Beluk dan Asas-Asas Hukum Perdata, Penerbit Alumni, Jakarta, Cet II, 
Subekti, R, dan Tjitrosudibio, R., 1983, Kitab Undang-undang Hukum Perdata, Pradnya Paramita, Jakarta.

Ali, Ahmad, 2012, Menjelajai Kajian Empiris Terhadap hukum, Kencana Prenada Media Group, Jakarta

Peraturan Perundang-Undangan:

Undang-undangNomor 35 Tahun 2014 tentang Perlindungan Anak

Peraturan Menteri Koordinator Bidang Kesra Republik Indonesia No 07 Tahun 2014 Tentang rencana aksi nasional perlindungan dan pemberdayaan perempuan dan anak Fatwa dari Majelis Ulama Indonesia tanggal 10 Maret 2012 tentang anak siri berhak atas wasiat wajibah

Undang-UndangNomor 1 Tahun 1974 TentangPerkawinan

Undang-UndangNomor 23 Tahun 2006 tentang Administrasi Kependudukan Putusan Mahkamah Konstitusi No. 46/PUU-VIII/2010tentang anak luar kawin yang tidak sempat diakui atau tidak pernah diakui oleh Pewaris 